\title{
Implementation Of Character Education In Elementary School Students
}

\author{
Jenny Lilawati \\ Basic Education Study Program, Postgraduate School \\ Universitas Negeri MEdan \\ Medan, North Sumatera, Indonesia \\ e-mail: jennylilawati@gmail.com
}

\begin{abstract}
Many of the issues evolving in education regarding student behavior tends to be negative. To overcome these negative behaviors that need to be developed character early on. This study aims to determine the implementation of character education in elementary school, the role of principals and teachers in fostering the student's character, and factors that affect the implementation of character education in schools. This study used descriptive qualitative research. Subject of the study consisted of principals, teachers, and students of Hamas Integrated Islamic Elementary School. Object of the study is implementation of character education in the classroom and in the school environment. Research data were collected through observation, interviews and document analysis. The research data were analyzed using data reduction, data presentation and conclusion. The results showed that the implementation of character education is executed in learning and teaching, exemplary by teacher, habituation, and extracurricular. The role of the principal is to make policy in developing the character of students, and teachers lead students to the values of good character. Factors that affect the implementation of character education are supporting factors and inhibiting factors. Supporting factors are school policies and parental support. Inhibiting factor are the lack of infrastructure, lack of conducive learning environment, and extracurricular not going well.
\end{abstract}

Keywords - character education; elementary school

\section{INTRODUCTION}

Education in schools should be the basis for the formation of student personality. But nowadays many issues develop in the education environment regarding behavior of students who tend to negative. Various news in electronic and non-electronic media that contains various actions that indicate unexpected characters, brawl between students, lack of courtesy to parents and elders, and teachers, sexual harassment, free sex, smoking and drugs, lying, cheating and other disrespectful behaviors and actions [1]. In addition, many cases of bullying that occurred in schools that are very worrying due to the victim. The biggest reason for this incident is due to the lack of development of the character values in the student.

Character issues are urgent and need to be handled immediately. One of way that can be done is to instill the values of character through education. Character education can serve as a preventive solution of declining national character [2]. The character education is an effort to foster the development of the souls of children both physical and spiritual, from their natural nature toward a humane and better civilization [3].

Character is a good potential trait, which can be identified through attitudes in daily deeds [4]. A good character related with knowing the good, loving the good, and acting the good. Knowing the good means understanding and differentiating between good and bad. Character is formed from the internalization of various policies that are believed and used as a basis for the worldview, thinking, attitude, and acting [5]. To form the values and character of a citizen can begin since a child is born in his family. But also be done through formal education in schools. School is one of the most effective means to implement, develop and succeed the national character education agenda because the school environment is the second place for students to spend time after at home.

Character education will be more embedded if done early [6]. Therefore, the development of character values should gets serious attention by teachers since the primary school level, so that the characters in students can develop well. This is because basic education is the main foundation for young people's growth. So that character education becomes very important to be planted starting from elementary school.

Implementation of character education in primary schools is integrated in learning. Primary school is a formal institution that became the foundation of education for the level of education on it. Teachings carried out by teachers of course expect the occurrence of changes in students who are not only in terms of cognitive but also affective aspects of students. Characters will be more easily impregnated by students when designed in learning.

The character of the child in the learning environment in the school is the character shown through attitudes toward the lessons, learning activities, teachers, friends, and daily activities. In general character education emphasizes exemplary, environmental creation, and habituation, through various scientific activities and conducive activities. Thus, what students see, hear, feel and do can shape their character. In addition to modeling and habituation as the primary educational method, creating a conducive climate and culture as well as a conducive environment is also very important, and contributes to the character of learners.

Characterized student are very important because the character is a moral behavior that will shape humanity in the 
future [7]. The character education of students is not only enough to know right-wrong and good-bad, but by behaving, acting and acting based on the values that become personality. By creating a conducive environment that can be done through a variety of methods, including: assignment, habituation, training, learning, direction, and exemplary. Expected to influence the formation of the character of learners. It can also be carried out activities containing elements of education, for example in scouting activities, there is an education of simplicity, independence, solidarity and togetherness, love of the environment and leadership. Through character education will be embedded values of good character and will manifest in everyday behavior. The values of character education applied in education in Indonesia are (1) Religious, (2) Honest, (3) Tolerance, (4) Discipline, (5) Hard Work, (6) Creative, (7) Independent, 8) Democratic, (9) curiosity, (10) nasionalism, (11) Love the Homeland, (12) Respect, (13) Friendly / Communicative, (14) peace loving, (15) 16) Care for the Environment, (17) Care for the Social, and (18) Responsibility [5].

Character education in schools will not work if the learning is just a verbalistic memorization. There is no guarantee that character education stands alone as a subject, it will work. Therefore, the implementation of character education in schools should be done by integrating in learning. This study aims to determine the implementation of character education in Elementary School, the role of principals and teachers in fostering the student's character, and factors that affect the implementation of character education in schools.

\section{METHOD}

This study used descriptive qualitative research. Subject of the study consisted of principals, teachers, and students of Hamas Integrated islamic Elemtary School. The object of research is the implementation of character education in the classroom and in the school environment. Research data were collected through observation, interviews and document analysis. The research data were analyzed using data reduction, data presentation and conclusion.

\section{RESULT AND DISCUSSION}

\section{A. Implementation of Character Education in Elementary School}

Character education includes both three components, namely moral knowing, moral feeling, and moral action [8]. These three components are the process of getting to a good character. Implementation of character education can be done with various methods that can support the achievement of good character in students. Character education in Hamas Integrated islamic Elementary School is conducted through teaching and learning activities, habituation, and also through extracurricular activities.

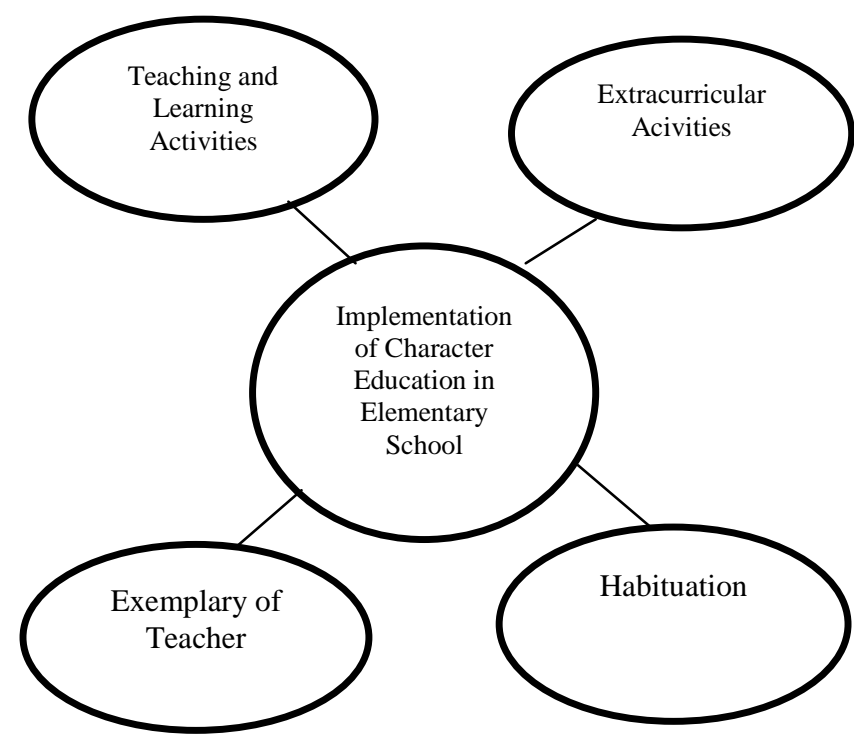

Fig 1. Implementation of Character Education

1) Implementation of character education through teaching and learning activities: Character education in teaching and learning activities is integrated through subjects delivered by teachers. The cultivation of character values through teaching and learning activities is done by incorporating the elements of character value through the subject matter applied through integrative thematic learning which is guided by lesson plan. Subject materials related to good values on each subject need to be developed and linked to the context of everyday life. Thus, character learning is not only on the cognitive aspect, but also connects with real-life experiences in everyday life. In addition, teachers also use varied learning methods such as discussion as a communicative / friendly value, designing experimental activities as a value of curiosity, assigning tasks so that students can learn independently.

2) Implementation of character education through the exemplary of teachers: Teachers have a role in building the character of students through exemplary. Exemplary becomes very important to overcome the problem of character and has a very big contribution in educating and fostering character [9]. Exemplary priority aspects of behavior in the form of real action and not just talking. Teachers should be able to position themselves as role models for students at school. Teachers are parents for students at school so that teachers are required to be good role models that can instill good character values for students. Teachers at Hamas Integrated islamic School have never had any legal, social and other problems. From this it means that the teachers at Hamas Integrated islamic Elementary School are already worthy of being role models. But teachers can not yet be an example for their students. Some teachers come late to school and happen quite often. This certainly has a bad effect because it will affect student discipline. For that teachers need to do an evaluation of himself so that the future will be a better example for students. 
3) Implementation of character education through habituation: Character education consists of eighteen national character values that should be implemented in schools to realize the character of learners who have good character. The value of characters performed in schools is developed through habituation of learners in behaving. Based on the observation, the value of characters developed through habituation attitude at school are:

- Before and after learning the students pray together, say their greetings, attend congregational prayers and ask permission when out and enter the classroom as an implementation of religious values

- Students undertake class cleanliness duty tasks and are taught to dispose of trash in the dumpster as an environmentally conscious implementation.

- Students perform flag ceremonies every Mondayas an implementation of the spirit value.

- Students arrive on time to school and dress according to the schedule specified as the value of the discipline

- Students perform arts performances at the end of each month as a value of creative and work

- Students are accustomed to apologize when making mistakes as a value of responsibility

4) Implementation of character education through extracurricular activities: Extracurricular program implemented to provide opportunities for students to develop their potential and foster creativity and independence in students to face challenges in the future. Extracurricular activities are educational activities beyond the subjects to develop their potential, talents, and interests. Through extracurricular activities is expected to develop the ability and sense of responsibility, and potential, and student achievement. Extracurricular in Hamas Integrated islamic Elementary School is a scout activity that is held every Saturday. This scout extracurricular activity is an appropriate means of shaping and developing the character of student responsibility, responsibility for oneself, responsibility for people, responsibility for nature, and responsibility for God [10]. The success of this extracurricular activity is supported by good relationships between principals and scout leaders, good programs, facilities and infrastructure and operational funds for operational needs of activities.

Based on the results of the above explanation it can be concluded that the values of characters developed in the School is friendly/communicative, independent, discipline, religious, care for the environment, nasionalism, and responsibility. The value of character that needs attention in this school is tolerance and peace loving. This is because there are still many students who fight, disrupt, and disrespect their friends. Though the teacher has given advice but there are still students who repeat the mistake again.

\section{B. The Role of Principals and Teachers in Fostering Student Character}

As a character education officer in schools, principals and teachers have an important role in fostering the character of students. In order to character education goals can be achieved, principal and teachers need to do good planning. In the implementation should be supervised in order to achieve the purpose.

Based on interview results, principals play a role in making policies and regulations to support the implementation of character education in schools. The principal organizes programs such as (1) tahfiz quran activities every Monday until Thursday (2) extracurricular activities of Scouts, (3) flag ceremony activities every Monday, and gymnastics on Friday and Saturday, (4) conduct evaluation of teaching and learning activities every month to monitor various problems in learning, (5) perform art performances at the end of each month.

Teachers have a role that is not less important than the principal. As a character education officer, teachers are the most influential students in the successful implementation of character education. Teachers have the responsibility of fostering students character both in teaching and learning activities by integrating it in learning activities. Teachers are also responsible for directing students to good character values by providing examples so that students can imitate and apply them properly. teachers with principal also need to monitor and evaluate the implementation of character education in order to perform well.

\section{Factors Affecting the Implementation of Character Education}

Factors affecting character education in Hamas Integrated islamic Elementary School are two, namely supporting factors and inhibiting factors. Factors supporting the implementation of character education in schools are:

1) School policy: School policies and programs created by principals can support the application of character education to be work. The school has a vision, mission and purpose that leads to the formation of religious character. The purpose of this school is to creat the generation of Rabbani who feared his God, love his Prophet, loving parents and can make country proud. Various activities are designed to realize that goal. To advance the School, vision and mission are defined namely; Vision: "Making citizens learn smart, skilled and useful for society and religion". Meanwhile the school mission is "By learning we will know, by learning we will understand, by learning we will be skilled, by learning we will make changes, by learning we will be useful". The principal designs various policies to achieve these objectives, such as making arrangements, extracurricular activities and routine habituation activities. Character education conducted through activity programs shows the commitment of school to implement the character education program on an ongoing basis.

2) Parental support: Parents' awareness of the importance of character education be the factors that support character education can be well off. Although there are some parents 
who are busy working and paying little attention to their children, there are also parents who are very concerned and can working along with teachers. Teachers and parents always communicate well to monitor students' ability to learn as well as their attitudes and behaviors.

Factors inhibiting the implementation of character education in schools are:

1) Lack of facilities and infrastructure: Schools have not yet provided optimal garbage dumps so that the garbage can become full and piled up fast, and the school environment becomes dirty. In addition, hygiene tools such as brooms and mop are very minimal and damaged, so students can not clean the class well. If this continuesly happen, then the implementation of care for the environment character will be disrupted.

2) Non-conducive environment: In this foundation there is not only elementary school, but also covers from kindergarten to senior high school. Characteristics of elementary school students who easily imitate what they sees feared would affect the implementation of character education negatively if what they saw could not reflect the value of good character. This kind of environment becomes unfavorable if at high school is not applied character education well, so the behavior of high school students can be a poor example for elementary school students.

3) Extracurricular that did not going well: Extracurricular implementation in Hamas Integrated islamic Elementary School did not go well. Activities that should be carried out every Saturday is rarely done due to various factors. The time that should be used for Scout activities would be empty and not doing any activities. This is because the scouts are less disciplined in carrying out these routine activities and also the number of those who are still too minimal so difficult to meet the demands of the implementation of activities to all students. In addition, schools often repatriate students earlier so students skip the extracurricular time. This is because the teachers have other activities outside of learrning.

\section{CONCLUSION}

Based on the results of research and discussion, it can be concluded that (1) the implementation of character education in elementary schools are through teaching and learning activities, teacher exemplary, habituation, and extracurricular activities. The character values developed in this School are friendly / communicative, independent, disciplined, religious, care for the environment, nationalism and responsibility. The value of character that needs attention in this school is tolerance and peace loving. (2) the role of the principal is to make various policies that support the implementation of character education such as tahfiz quran activities every Monday to Thursday, extracurricular activities Scouts, flags ceremony activity every Monday, and gymnastics on Friday and Saturday, conducting evaluation of teaching and learning activities every month to monitor various problems in learning, perform art performances at the end of each month. While the role of the teacher is to foster the character of students both in teaching and learning activities from by integrating in teaching and learning activities. In addition, teachers are also responsible for directing students to the values of good character by providing examples so that students can imitate and apply them properly (3) factors that influence the character education there are two factors that supporting and inhibiting implementation character education. Supporting factors are school policy and parent support. Inhibiting factors are lack of facilities and infrastructure, less conducive learning environment, and extracurricular activities that do not work well.

\section{REFERENCES}

[1] Nurchaili. 2010. Membentuk Karakter Siswa Melalui Keteladanan Guru. Jurnal Pendidikan dan Kebudayaan, 16(3):233-244

[2] M. Wahyuni and A. Mustadi. 2016. Developing Collaborative Learning Kits Based on Local Wisdom to Enhance Creative and Friendly Character. Jurnal Pendidikan Karakter, 4(2):246-260

[3] E. Mulyasa. 2014. Pengembangan dan Implementasi Kurikulum 2013. Bandung: Remaja Rosdakarya

[4] H. Kurniawan. 2016. Sekolah Kreatif: Sekolah Kehidupan yang Menyenangkan untuk Anak. Yogyakarta: Ar-Ruzz Media

[5] D. Setiawan. 2017. Pendidikan Ilmu Pengetahuan Sosial. Medan: Larispa

[6] S. Mardikarini and Suwarjo. 2016. An Analysis of Character Values Content in the 2013 Curriculum Course-Book of Teacher Handbokk and Student's Handbook. Jurnal Pendidikan Karakter, 4(2):261-274

[7] U. Wuryanti and B. Kartowagiran. 2016. Developing Animaton Video Media to Improve Learning Motivation And Character Hard Work on the Fifth Grade Student of Elementary School. Jurnal Pendidikan Karakter, 4(2):232-245

[8] T. Lickona. 2013. Pendidikan Karakter Panduan Lengkap Mendidik Siswa Menjadi Pintar dan Baik. Terj. Lita S. Bandung: Nusa Media

[9] D. Prasetyo and Marzuki. 2016. Building Character Through the Example of Citizenship Education Teachers in Al Azhar Islamic School of Yoyakarta. Jurnal Pendidikan Karakter, 4(2):215-231

[10] S. Woro and Marzuki. 2016. The Role of Scouting Extracurricular Activities in Building the Student's Character of Responsibility in SMP Negeri 2 Windusari Magelang. Jurnal Pendidikan Karakter, 4(1):59-73 